\title{
Scope and Prospects of Agricultural Production in Kolhapur District of Maharashtra, India
}

\author{
N.K. Meena ${ }^{1 *}$, B.B. Gawade ${ }^{2}$, H.R. Shinde ${ }^{2}$, G.N. Gurjar ${ }^{1}$ and N. laitonjam ${ }^{1}$ \\ ${ }^{1}$ College of Post Graduates studies, CAU, Umiam, Meghalaya, India \\ ${ }^{2}$ College of Agriculture, Kolhapur, Maharashtra, India \\ *Corresponding author
}

\section{A B S T R A C T}

\begin{tabular}{|l|}
\hline Key w or d s \\
$\begin{array}{l}\text { Scope and prospects } \\
\text { of agriculture, Wheat, } \\
\text { kharif. }\end{array}$ \\
\hline Article Info \\
\hline $\begin{array}{l}\text { Accepted: } \\
\text { 17 September } 2017 \\
\text { Available Online: } \\
\text { 10 November } 2017\end{array}$ \\
\hline
\end{tabular}

The present study was conducted in Kolhapur district of Maharashtra state during 1980-81 to 2011-12. The study found that area under wheat, bajra, gram, redgram had declined and area under rice, Kharif jowar, Rabi jowar, greengram, blackgram, fruits and vegetables, soybean sugarcane and groundnut was increased. Similarly area under total cereal and pulse was also declined. The growth rates in area, production and productivity of oilseeds for entire period have turned out to be positive and increased at the rate of 2.02, 3.65 and 1.43 , respectively. Among the different cash crops cotton was positive and highly significant in period II, and III, except productivity in period III negatively significant. Sugarcane had a positive and significant growth rates for area, production and productivity as $25.98,31.71$ and 5.07 per cent, respectively. This might be attributed growth of sugar factory increased. From the above analysis, it can be concluded that there exist wide variability in the performance of individual crops in terms of changes in their performance, total production, productivity in the district over a period under study.

\section{Introduction}

Maharashtra is considered to be one of the heterogeneous states in India as far as the varying agro-climatic conditions are concerned. The state comprises four region viz., Konkan, Western Maharashtra, Marathwada and Vidarabha with represent varying types of natural, physical, social and economic conditions, quite distinct from each other (GoM, 2013). The variability in topography, soil and climatic factors bear significant impact on crop and land use pattern, use of production inputs and adoption of technological innovations of crop production among the region. The geographical area of Maharashtra is 30, 7713 $\mathrm{km}^{2}$, approximately 140-145 lakh hectare of land is cultivated in the Kharif season and 6065 lakh hectares in Rabi season. The food grains production was decreased by 23 per cent with the production of 118.09 lakh metric tonne in the year 2012-13 as against 154.19 lakh metric tonnes during the previous year i.e., 2011-12 due to heterogeneous variability of agro-climatic conditions (GoI, 2014). The variability in topography, soil and climatic factors bear significant impact on crop and land use pattern, use of production inputs and adoption of technological innovation of crop production among the region. 
Kolhapur is of the major developed district of Maharashtra in terms of agriculture and because of this reason it is considered as hub of agriculture. The soil of Kolhapur district is vertisol (black cotton soil) which is more suitable for cultivation of cash crops like cotton, sugarcane etc.

About 7, 74,977 hectares land of state was available for agricultural activities and about 44.62 per cent of total populations of Kolhapur district was depend on agriculture. Out of total workers in the district about 39.23 per cent workers were cultivators. The agricultural labourers accounted for 14.91 per cent to total workers in the district.

The population engaged in cottage and household industries, trade and commerce, mining and transport, services, etc., was negligible. Keeping in mind these above factors we have undertaken this study to find out the change in land use, cropping pattern and growth rate in different crops in Kolhapur district of Maharashtra.

\section{Materials and Methods}

The analysis was done based on the secondary data collected from various sources viz., published statistical literature and by contacting officials of the Zilla Parishad, Cooperative and District Statistical Office of the Kolhapur district, www. agricoop.nic.in, district census hand book, season and crop report published by department of Agriculture Maharashtra, Epitome of Agriculture, ministry of Agriculture govt. of India, Season and Crop Reports published by the Department of Agriculture, Maharashtra State (Bhagat,1983), (GoI, 2013), (GoM, 2014). Secondary data were collected for a period of 32 years divided into three periods viz., 198081 to $1994-95,1995-1996$ to $2011-12$ and also for the whole period from1980-81 to 2011-12.
The change in land use and cropping pattern

The analysis was done through simple tabular analysis

\section{Growth rate estimation}

The compound growth rates were worked out by fitting exponential function of the following type to the data for three periods explained above (Bobade, 2003).

$Y=a b^{t}$

Or

$\log \mathrm{Y}=\log \mathrm{a}+\mathrm{t} \log \mathrm{b}$

Where,

$\mathrm{Y}=$ Area in hectares, production in quintals and yield in quintals per hectare,

$\mathrm{a}=$ Intercept,

$\mathrm{b}=$ regression coefficient,

$\mathrm{t}=$ time period in years.

Finally the annual rate of compound growth in area, production and productivity of the crops was worked out by using the formula.

$r=($ Antilog b-1) x 100

The significance of the estimated compound growth rates were tested with the help of Students' t test.

\section{Results and Discussion}

\section{The change in land use pattern}

The area of uncultivable land of state had decreased from 5.34 per cent to 5.15 per cent 
during the period of 32 years. It means uncultivable land had converted into cultivable land. However, in another side land under non-agricultural use was also increased from 0.317 lakh hectares to 0.382 lakh hectares during the period from 1980-81 to 2011-12. It indicates that cultivable and waste land was used for construction of buildings, roads, establishment of new industries etc. The cultivable waste land area was showed decline from 0.657 to 0.396 lakh hectare from 1980-81 to 2011-12 i.e. 4.75 per cent of the total geographical area of the state. There is urgent need to minimize the use of cultivable waste land for non-agricultural development. The area under permanent pastures from 0.415 to 0.418 lakh hectares and land under miscellaneous trees increased over a period of time. The area under forest was 1.469 lakh hectares i.e. 18.69 per cent of the total geographical area in 1980-81, which declined to 1.407 lakh hectares in 2011-12, i.e., by 4.22 per cent over the base year. The forest was reduced may be due to deforestation for establishment of new industries, construction of government and non-government buildings, roads and to meet several requirement of increasing human population of the state. Ecological balance of Kolhapur district had adversely affected because of maximum deforestation, and is very difficult to maintain it. The net sown area of Kolhapur district was 4.254 lakh hectares $(54.12 \%)$ during 1980-81, which increased significantly in 1995-96 to 2011-12 but decreased in 198081 to 2011-12. It was 4.628 lakh hectares in 1995-96 i.e., 60.22 per cent to the geographical area and it declined to 4.306 lakh hectares i.e., 55.45 per cent to the total geographical area in 2011-12.

The irrigated area was reported to increase during entire period from 1980-81 to 20112012 , it is increased by 79.77 per cent over the base year. In 1980-81, irrigated area was 0.712 lakh hectares. Due to increasing irrigation facilities and utilizing cultivable waste land for cultivation purpose the proportion of unirrigated area to irrigated area was decreased.

The gross cropped area was increased from 56.69 per cent to 85.64 per cent in the study period, it was increased in 1995-96 i.e. 5.362 lakh hectares i.e., 69.77 per cent and in 201112 increased up to 6.650 lakh hectares i.e. 85.61 per cent to the total geographical area. It was increased significantly and is a good indication of agricultural development. The cropping intensity which is measure of land use efficiency did not show much change during 1980-81 to 2011-12. The range of cropping intensity was reported from 104.69 to $154.43 \%$ during the period of $1995-96$ to 2011-12. The result of this study showed that area under forests, barren land, uncultivable waste land and current fallow declined sharply during the period of the study. While gross cropped area, net sown area and irrigated area showed increasing trend.

\section{Changes in the cropping pattern of food grains and non-food grain crops}

The details regarding the changes in the cropping pattern of Kolhapur district presented in Table 1. It can be seen from the Table that the area under rice increased from 1.051 lakh hectares in 1980-81 to the 1.115 lakh hectares in 2011-2012. But it showed increasing over time period, in 1995-96 it was increased 1.074 lakh hectares similarly it was increased 1.115 lakh in 2011-12. The area under wheat decreased from 0.118 lakh hectares in $1980-81$ to 0.086 lakh hectares in 2011-12 i.e. from 2.64 per cent to 1.29 per cent of the gross cropped area. The area under Kharif jowar increased in second, third period as compared to base year. Similarly the area under Rabi jowar showed fluctuations. It was $0.009,0.003$, and 0.140 , lakh hectares in 1980-81, 1995-96 and 2011-12 respectively. Area under bajra showed decreasing trend except in 1995-96, it increased over base year. 
The total cereals showed declining in second and third period of study. Area under Gram was 0.089 lakh hectares in 1980-81 and decreased up to 0.086 lakh hectares in 201112 i.e. from 1.99 per cent to 1.27 per cent and area under red gram declined over base year because area of gram and red gram was shifted for cash crops. Green gram increased from 0.004 lakh hectares to 0.030 lakh hectares from 1980-81 to 2011-12 i.e. from 0.08 per cent to 0.45 per cent. Area under total pulses decreased from 0.288 lakh hectares to 0.218 lakh hectares i.e., 6.46 per cent to 3.28 percent from 1980-81 to 2011-12. Area under total food grains also decreased from 2.433 lakh hectares to 2.004 lakh hectares from 1980-81 to 2011-12. Area under sugarcane showed tremendous increase in area due to increase in number of sugar industry and jaggery making unit. It was 0.500 lakh hectare in 1980-81 and increased up to 1.399 lakh hectares in 2011-2012. Area under fruits and vegetables increased from 0.029 lakh hectares to 0.153 lakh hectares due to Maharashtra Governments launched orchard plantation programme. Area under cotton showed decreasing. Another crops among oilseeds, groundnut showed fluctuations in area. Total oilseeds showed increasing trend from 0.516 lakh hectares to 1.124 lakh hectares from 1980-81 to 2011-12. It was seen from the table that the area under commercial crops is increasing viz., sugarcane except cotton.

Table.1 Structural changes in land use

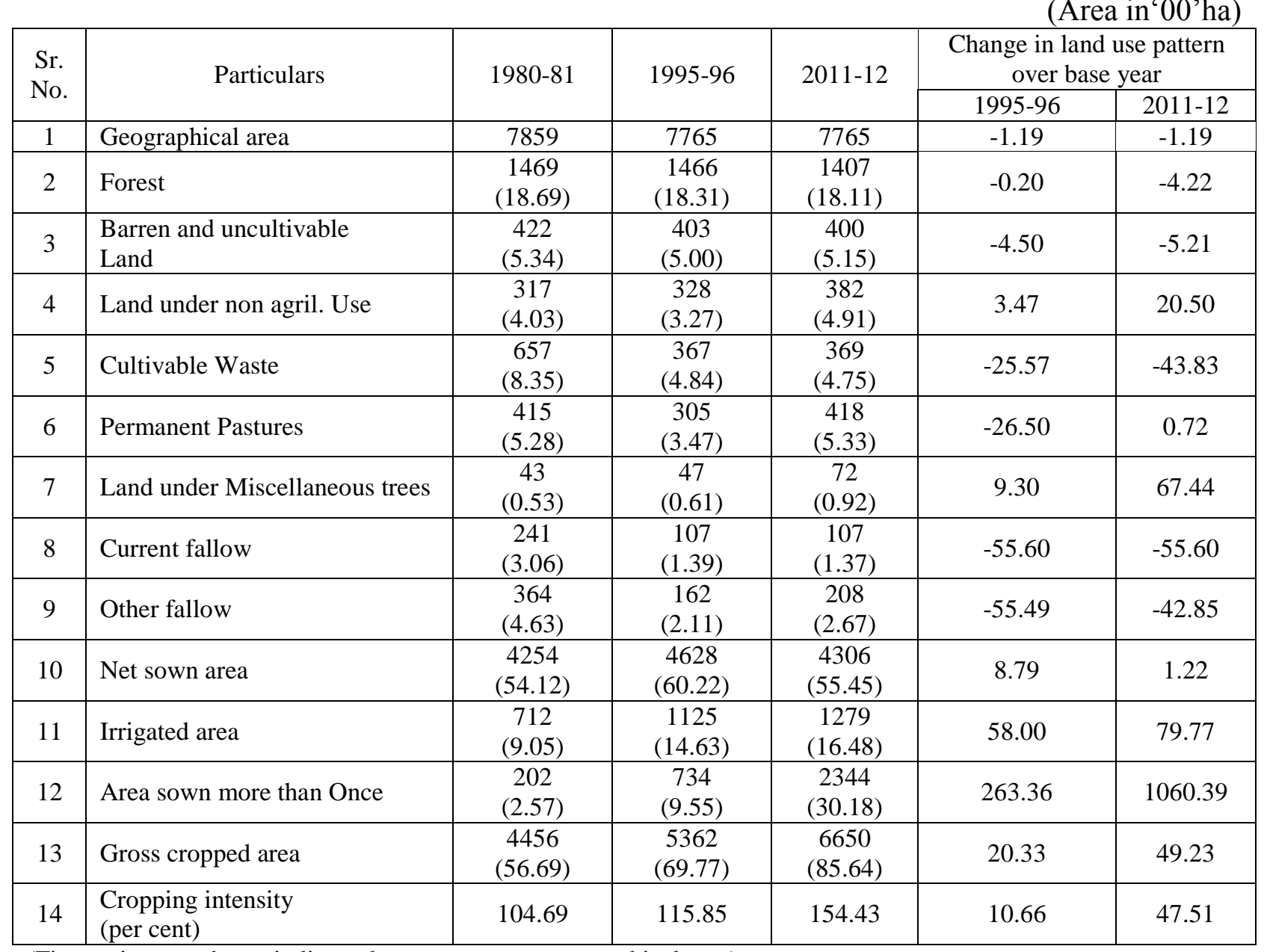

(Figures in parentheses indicate the percentage to geographical area) 
Table.2 Changes in the cropping pattern of Kolhapur district of Maharashtra

\begin{tabular}{|c|c|c|c|c|c|c|}
\hline \multirow[t]{2}{*}{$\begin{array}{l}\text { Sr. } \\
\text { No. }\end{array}$} & \multirow[t]{2}{*}{ Particulars } & \multirow[t]{2}{*}{ 1980-81 } & \multirow[t]{2}{*}{$1995-96$} & \multirow[t]{2}{*}{ 2011-12 } & \multicolumn{2}{|c|}{$\begin{array}{l}\text { Percent change in cropping } \\
\text { pattern over base year } 1980-81\end{array}$} \\
\hline & & & & & $1995-96$ & $2011-12$ \\
\hline 1 & Rice & $\begin{array}{c}1051 \\
(23.58) \\
\end{array}$ & $\begin{array}{c}1074 \\
(20.02) \\
\end{array}$ & $\begin{array}{c}1115 \\
(16.76) \\
\end{array}$ & 2.1 & 6.08 \\
\hline 2 & Wheat & $\begin{array}{c}118 \\
(2.64)\end{array}$ & $\begin{array}{c}94 \\
(1.75)\end{array}$ & $\begin{array}{c}86 \\
(1.29) \\
\end{array}$ & -20.33 & -27.11 \\
\hline 3 & Kharif-jowar & $\begin{array}{c}34 \\
(0.76)\end{array}$ & $\begin{array}{c}96 \\
(1.79)\end{array}$ & $\begin{array}{c}80 \\
(1.20)\end{array}$ & 182.35 & 135.29 \\
\hline 4 & Rabi- jowar & $\begin{array}{c}9 \\
(0.20) \\
\end{array}$ & $\begin{array}{c}3 \\
(0.05) \\
\end{array}$ & $\begin{array}{c}14 \\
(0.21) \\
\end{array}$ & $\begin{array}{l}-66.66 \\
\end{array}$ & 55.55 \\
\hline 5 & Bajra & $\begin{array}{c}26 \\
(0.58)\end{array}$ & $\begin{array}{c}58 \\
(1.08) \\
\end{array}$ & $\begin{array}{c}24 \\
(0.36)\end{array}$ & 123.07 & -7.6 \\
\hline \multirow[t]{2}{*}{6} & Others & $\begin{array}{c}907 \\
(20.35) \\
\end{array}$ & $\begin{array}{c}512 \\
(9.54) \\
\end{array}$ & $\begin{array}{c}465 \\
(5.78) \\
\end{array}$ & -43.55 & -48.73 \\
\hline & Total Cereals & $\begin{array}{c}2145 \\
(48.13) \\
\end{array}$ & $\begin{array}{c}1837 \\
(34.25)\end{array}$ & $\begin{array}{c}1786 \\
(26.85)\end{array}$ & -14.35 & -16.73 \\
\hline 7 & Gram & $\begin{array}{c}89 \\
(1.99)\end{array}$ & $\begin{array}{c}86 \\
(1.60)\end{array}$ & $\begin{array}{c}85 \\
(1.27)\end{array}$ & -3.37 & -4.49 \\
\hline 8 & Redgram & $\begin{array}{c}49 \\
(1.09)\end{array}$ & $\begin{array}{c}29 \\
(0.54) \\
\end{array}$ & $\begin{array}{c}24 \\
(0.36)\end{array}$ & -40.8 & -51.02 \\
\hline 9 & Greengram & $\begin{array}{c}4.00 \\
(0.08)\end{array}$ & $\begin{array}{c}16 \\
(0.29)\end{array}$ & $\begin{array}{c}30 \\
(0.45)\end{array}$ & 300 & 650 \\
\hline \multirow[t]{3}{*}{10} & Blackgram & $\begin{array}{c}10 \\
(0.22)\end{array}$ & $\begin{array}{c}34 \\
(0.63) \\
\end{array}$ & $\begin{array}{c}25 \\
(0.37)\end{array}$ & 240 & 150 \\
\hline & Total pulses & $\begin{array}{c}288 \\
(6.46)\end{array}$ & $\begin{array}{c}257 \\
(4.79)\end{array}$ & $\begin{array}{c}218 \\
(3.28)\end{array}$ & 10.76 & -24.30 \\
\hline & Total food grains & $\begin{array}{c}2433 \\
(54.60)\end{array}$ & $\begin{array}{c}2094 \\
(39.05)\end{array}$ & $\begin{array}{c}2004 \\
(30.13)\end{array}$ & -13.93 & -17.63 \\
\hline 11 & Sugarcane & $\begin{array}{c}500 \\
(11.22)\end{array}$ & $\begin{array}{c}900 \\
(16.78)\end{array}$ & $\begin{array}{c}1399 \\
(21.03)\end{array}$ & 80 & 179.8 \\
\hline 12 & $\begin{array}{l}\text { Fruits and } \\
\text { vegetables }\end{array}$ & $\begin{array}{c}29 \\
(0.65) \\
\end{array}$ & $\begin{array}{c}81 \\
(1.51) \\
\end{array}$ & $\begin{array}{c}153 \\
(2.3) \\
\end{array}$ & 179.3 & 427.58 \\
\hline 13 & Cotton & 5 & 3 & 2 & -40 & -60 \\
\hline 14 & Groundnut & $\begin{array}{c}500 \\
(11.22)\end{array}$ & $\begin{array}{c}610 \\
(11.37)\end{array}$ & $\begin{array}{c}583 \\
(8.76)\end{array}$ & -22 & 16.6 \\
\hline \multirow[t]{3}{*}{15} & Soybean & $\begin{array}{c}200 \\
(4.48)\end{array}$ & $\begin{array}{c}440 \\
(8.20)\end{array}$ & $\begin{array}{c}485 \\
(7.29)\end{array}$ & 120 & 142.5 \\
\hline & Others & $\begin{array}{c}16 \\
(0.35) \\
\end{array}$ & $\begin{array}{c}92 \\
(1.71) \\
\end{array}$ & $\begin{array}{c}56 \\
(0.84) \\
\end{array}$ & 475 & 250 \\
\hline & Total oilseeds & $\begin{array}{c}716 \\
(11.57) \\
\end{array}$ & $\begin{array}{c}1142 \\
(21.29)\end{array}$ & $\begin{array}{c}1124 \\
(16.90)\end{array}$ & 59.49 & 56.98 \\
\hline 16 & Other crops & $\begin{array}{c}978 \\
(21.94) \\
\end{array}$ & $\begin{array}{c}1145 \\
(21.35) \\
\end{array}$ & $\begin{array}{c}1952 \\
(29.53) \\
\end{array}$ & 17.07 & 99.59 \\
\hline 17 & Gross cropped area & 4456 & 5362 & 6650 & 20.33 & 49.23 \\
\hline
\end{tabular}

(Figures in parentheses indicate percentage to gross cropped area)

Source: - Season and Crop Reports published by the Department of Agriculture, Maharashtra. 
Table.3 Area, production and yield growth in different periods in Kolhapur district in Maharashtra

\begin{tabular}{|c|c|c|c|c|c|c|c|c|c|c|}
\hline $\begin{array}{c}\text { Sr. } \\
\text { No. }\end{array}$ & Crops & \multicolumn{3}{|c|}{$\begin{array}{c}\text { Period I } \\
(1980-81 \text { to 1995-96) }\end{array}$} & \multicolumn{3}{c|}{$\begin{array}{c}\text { Period II } \\
\text { (1995-96 to 2011-12) }\end{array}$} & \multicolumn{3}{c|}{$\begin{array}{c}\text { Over all period } \\
\text { (1980-81 to 2011-12) }\end{array}$} \\
\hline & & $\mathrm{A}$ & $\mathrm{P}$ & $\mathrm{Y}$ & $\mathrm{A}$ & $\mathrm{P}$ & $\mathrm{Y}$ & $\mathrm{A}$ & $\mathrm{P}$ & $\mathrm{Y}$ \\
\hline 1 & Groundnut & $3.30^{* * *}$ & $7.22^{* * *}$ & $4.05^{* * *}$ & $28.28^{* *}$ & 16.17 & -1.78 & $24.17^{* * *}$ & $23.15^{* * *}$ & $-2.14^{*}$ \\
\hline 2 & Safflower & $-11.44^{* *}$ & $-11.66^{* *}$ & $8.55^{* * *}$ & $-3.80^{* *}$ & $3.22^{* * *}$ & $-2.2^{* * *}$ & $-22.54^{* * *}$ & $23.1 * *$ & $9.5^{* * *}$ \\
\hline 3 & Soybean & $68.75^{* * *}$ & $80.35^{* * *}$ & $106.09^{* * *}$ & $22.55^{*}$ & $29.40^{* *}$ & 1.54 & $56.80^{* * *}$ & $61.39^{* * *}$ & $33.37 * * *$ \\
\hline 4 & $\begin{array}{c}\text { Total } \\
\text { oilseed }\end{array}$ & -0.22 & 0.193 & 0.42 & -0.02 & 2.33 & 0.74 & $2.02^{* * *}$ & $3.65^{* * * *}$ & $1.43^{* * *}$ \\
\hline 5 & Cotton & $-11.24 * * *$ & -6.60 & $3.57 * *$ & $22.52^{*}$ & $26.09^{* * *}$ & 7.55 & $17.08^{* * *}$ & $22.01^{* * *}$ & $-6.64^{*}$ \\
\hline 6 & Sugarcane & $3.25^{* * *}$ & $25.53^{* * *}$ & $20.64 * * *$ & $27.80^{* *}$ & $23.01^{*}$ & 0.51 & $25.98^{* * *}$ & $31.71^{* * *}$ & $5.07^{* *}$ \\
\hline
\end{tabular}

Area under soybean crop increased 10.20 percent in 2011-12 over the base year take 1995-96. Among pulses studied for the Kolhapur district, total pulses growth rates for overall period were positive and highly significant. Black gram, green gram and red gram had positive and significantly higher growth rates over entire period thirty two years of study. Red gram productivity decreasing in period III but its area, and production had positive and significant growth rates over period II and III. The total food grain area, production and productivity fluctuate over study period. The production and productivity of food grain increasing positively and highly significant during period I (1980-81 to 1994-95) compare to period II (1995-96 to 2011-12) and period III (1980-81 to 2011-12).

To sum up it can be said that the area under total cereals, total pulses and total food grains showed declined trend. While area under total oilseed crops showed increasing trend over the entire study period. Area under fruits and vegetables, sugarcane, groundnut and soybean also showed increasing trend under entire study period. Indicates more emphasis was given market led production system.

Similar results were obtained by Johl and Sing (1966), Naikawadi (1980) and Pawar et al., (1991).
Growth rate in area, production and productivity of total oilseeds and commercial crops

The area, production and productivity of total oilseeds, cotton and sugarcane crop had fluctuated widely during the period under study in Kolhapur district. The growth rates in area, production and productivity of oilseeds for entire period have turned out to be positive and increased at the rate of 2.02, 3.65 and 1.43. The growth rates for period III (1980-81 to 2011-12) were 2.02, 3.65 and 1.43, which were positive and highly significant showing satisfactory growth rate (Table 2). However it decreased in period II. The crop of groundnut is the important oilseed crop in Kolhapur district. The area production and productivity of groundnut had positively and highly significant during period I, II and III, except productivity of groundnut in period III negatively significant (Table 2). The growth rate of soybean in area, production and productivity had positive and highly significant during period under study. The growth rates in area production and productivity of soybean crop increased at (56.80, 61.39 and 33.37) in entire period of study. Among the different cash crops cotton was positive and highly significant in period II, and III, except productivity in period III negatively significant. Sugarcane had a positive and significant growth rates for area, 
production and productivity as $25.98,31.71$ and 5.07 per cent, respectively. This may be attributed growth of sugar factory increased. From the above analysis, it can be concluded that there exist wide variability in the performance of individual crops in terms of changes in their performance, total production, productivity in the district over a period under study. Thus, it clearly indicated that progress of agricultural development in Kolhapur district and its positive effect (Table 3).

The development process in Kolhapur district is a continuous process. It is boosted after adoption of new strategy of agricultural development. Adoption of new modern technology caused a shift from traditional agriculture to modern agriculture, subsistence to commercial, extensive cultivation to intensive cultivation and from low income enterprises to high income enterprises. It gives new idea, views to farmers so that they become conscious about the development of basic assets i.e. land and other diverted resources. The changes in growth rates of area, production and yield of major crops due to use of modern technology was also examined. The present study explain the processed facts regarding structural changes in the land use and cropping pattern as a result of agricultural development during the period from 1980-81 to 2011-12 in Kolhapur district.

The study concluded that area under wheat, bajra, gram and redgram declined. The area under rice, Kharif jowar, Rabi jowar, green gram, blackgram, fruits, vegetables, soybean, sugarcane and groundnut was increased, while area under total cereals and total pulse was declined and the area under total oilseeds showed increasing trend over the study period in Kolhapur district. The growth rates in area, production and productivity of oilseeds for entire period have turned out to be positive and increased at the rate of 2.02, 3.65 and
1.43. Among the different cash crops cotton was positive and highly significant in period II, and III, except productivity in period III negatively significant. Sugarcane had a positive and significant growth rates for area, production and productivity as $25.98,31.71$ and 5.07 per cent, respectively. Sugarcane had a positive and significant growth rates for area, production and productivity as 25.98 , 31.71 and 5.07 per cent, respectively. This may be attributed growth of sugar factory increased. From the above analysis, it can be concluded that there exist wide variability in the performance of individual crops in terms of changes in their performance, total production, productivity in the district over a period under study.

\section{References}

Awasthi, R. P. 1986. Crop production. Annual report. Indian Council of Agricultural Research Complex for NEH Region, Meghalaya, India, pp: 120.

Basnet, S. K. 2006. An economic appraisal of agricultural development in Nepal. (Unpublished) M. Sc. (Agri.) Thesis submitted to MPKV, Rahuri, Maharashtra.

Bhagat, L. N. 1983. Inter-regional disparities in agricultural infrastructure- A case study of Bihar. Indian J. Agric. Econ, 38 (1): 56-62.

Bobade, M.T. 2003. An economic appraisal of agricultural development in Satara district. (Unpublished) M. Sc. (Agri.) Thesis, MPKV, Rahuri.

Directorate of Economics and Statistics (2014). Economic survey of Maharashtra (2014-15). Directorate of Economics and Statistics, Planning Department, Government of Maharashtra, Mumbai, pp: 1-223.

GoM. (2013). Report of the high level committee on balanced regional development issues in Maharashtra. 
Government of Maharashtra, Planning Department, pp: 1-567.

Hanumantha, R. 1989. State wise production growth rates for rice and food grains. Indian J. Agril. Econ., 22(2): 61-79.

http://www.Indiastat.com/table. Accessed on 24 February 2015.

Jagnnathan, N. 1998. Trends and patterns of agricultural growth across crops in India. Monthly Public Opinion Surveys. 43 (5): 7-11.

Kapil, B. 2012. Economic appraisal of agricultural development in Himachal
Pradesh. Thesis submitted to MPKV, Rahuri.

Rahane, R. K. and Joshi, G. G. 1993. Growth rates in area, production and productivity of some important oilseeds and pulses in Maharashtra. Indian $J$. Agril. Econ., 48: 41.

Rahane, R. K. and Kasar, D. V. 1999. Regional variations in development of irrigation and its utilization in Maharashtra. Maha. J. Agril. Econ., 9: 142.

\section{How to cite this article:}

Meena, N.K., B.B. Gawade, H.R. Shinde, G.N. Gurjar and Laitonjam, N. 2017. Scope and Prospects of Agricultural Production in Kolhapur District of Maharashtra. Int.J.Curr.Microbiol.App.Sci. 6(11): 2478-2485. doi: https://doi.org/10.20546/ijcmas.2017.611.291 